\title{
KALSIUM KARBONAT PADA MEDIA BERSALINITAS UNTUK PERTUMBUHAN BENIH IKAN PATIN (Pangasius sp.)
}

\author{
CALCIUM CARBONATE IN THE WATER SALINITY TO THE GROWTH OF \\ SEEDLING CATFISH (Pangius sp.)
}

\author{
Yuni Puji Hastuti ${ }^{1}$, Kurnia Faturrohman ${ }^{1}$, Kukuh Nirmala \\ ${ }^{1}$ Departemen Budidaya Perairan \\ Fakultas Perikanan dan Kelautan, Institut Pertanian Bogor \\ Korespondensi : yuni_ph2@yahoo.com
}

\begin{abstract}
The development of technology and production systems in the field of aquaculture is one of the primary solutions for increasing production to cope with the presence of fishing is mainly about stripped catfish seed. Seed quality improvement through lime addition for the availability of minerals in the water supply and maintenance of media in salinity $4 \mathrm{~g} / \mathrm{L}$ which aims to suppress the level to support availability of employment of the inaugural thereby reducing energy used for osmoregulation and can be allocated to growth of catfish. Catfish seed size used was $2.69 \pm 0.04 \mathrm{~cm}$ and weight used was $0.08 \pm 0.01 \mathrm{~g}$. Aquarium used measuring $30 \times 15 \times 25 \mathrm{~cm}$ by as much as 15 units and filled water in salinity $4 \mathrm{~g} / \mathrm{L}$ as much as 9 litres per unit and added lime $\mathrm{CaCO} 3$ according treatment that was $\mathrm{K}(0 \mathrm{mg} / \mathrm{L} \mathrm{CaCO} 3)$, A (150 mg/L CaCO3), B (200 mg/L CaCO3), C (250 mg/L CaCO3) and D (300 mg/L CaCO3). For research, fish was fed on of a protein $(28 \%)$ as much as 3 times a day by FR 5\%. The addition of $\mathrm{CaCO} 3$ treatment for all treatment generated a level of survival as much as $(100 \%)(\mathrm{P}>0.05)$. While growth rate of weights daily each treatment in a consecutive manner that is $(11.34 \%) ;(12.06 \%) ;(11.51 \%) ; 12.67 \%$; and $(11.58 \%)(\mathrm{P}>0.05)$. Absolute value of different length produce $2.84 \mathrm{~cm} ; 4.63 \mathrm{~cm} ; 3.23 \mathrm{~cm} ; 3.79 \mathrm{~cm}$; and $3.28 \mathrm{~cm}(\mathrm{P}>0.05)$. During the research, the quality of the water was in the range that can be tolerated by the seed of catfish. The use of lime $\mathrm{CaCO} 3$ on salinity $4 \mathrm{~g} / \mathrm{L}$ recommended as much as $250 \mathrm{mg} / \mathrm{L} \mathrm{CaCO} 3$ with a turn of the water at regular intervals and feeding.
\end{abstract}

Keywords: calsium carbonate, catfish, growth, salinity

\begin{abstract}
ABSTRAK
Pengembangan teknologi dan sistem produksi dalam bidang perikanan budidaya merupakan salah satu solusi utama bagi upaya peningkatan produksi perikanan terutama untuk mengatasi adanya kendala tentang ketersediaan benih ikan patin. Perbaikan kualitas benih patin diupayakan melalui penambahan kapur untuk ketersediaan mineral di perairan dan pengadaan media pemeliharaan bersalinitas $4 \mathrm{~g} / \mathrm{L}$ yang bertujuan untuk menekan tingkat kerja osmotik sehingga mengurangi energi yang digunakan untuk osmoregulasi dan dapat dialokasikan untuk pertumbuhan ikan patin. Benih ikan patin yang digunakan berukuran $2,69 \pm 0,04 \mathrm{~cm}$ dengan bobot $0,08 \pm 0,01 \mathrm{~g}$. Akuarium yang digunakan berukuran 30 x 15 x $25 \mathrm{~cm}$ sebanyak 15 unit dan diisi air bersalinitas $4 \mathrm{~g} / \mathrm{L}$ sebanyak 9 liter per unit dan ditambahkan kapur CaCO3 sesuai perlakuan yaitu K (0 mg/L CaCO3) , A (150 mg/L CaCO3), B (200 mg/L CaCO3), C (250 mg/L CaCO3) dan D $(300 \mathrm{mg} / \mathrm{L} \mathrm{CaCO} 3)$. Selama penelitian, ikan diberi pakan dengan kadar protein (28\%) sebanyak 3 kali sehari dengan FR (5\%). Perlakuan penambahan $\mathrm{CaCO} 3$ untuk semua perlakuan menghasilkan tingkat kelangsungan hidup sebesar 100\% $(\mathrm{P}>0,05)$. Sedangkan laju pertumbuhan bobot harian masing-masing perlakuan secara berturut-turut yaitu $(11.34 \%)$; (12.06\%); (11.51\%); (12.67\%); dan (11.58\%) (P>0,05). Panjang mutlak menghasilkan nilai berbeda nyata yaitu 2.84 $\mathrm{cm} ; 3.62 \mathrm{~cm} ; 3.23 \mathrm{~cm} ; 3.79 \mathrm{~cm}$; dan $3.28 \mathrm{~cm}(\mathrm{P}<0,05)$. Selama penelitian, kualitas air berada dalam kisaran yang dapat ditoleransi oleh benih ikan patin. Penggunaan kapur $\mathrm{CaCO} 3$ pada salinitas $4 \mathrm{~g} / \mathrm{L}$ disarank sebanyak $250 \mathrm{mg} / \mathrm{L} \mathrm{CaCO} 3$ dengan pergantian air secara berkala dan pemberian pakan yang cukup.
\end{abstract}

Kata kunci: calsium carbonate, patin, pertumbuhan, salinitas 


\section{PENDAHULUAN}

Ikan patin (Pangasius sp.) merupakan salah satu komoditas ikan air tawar yang sudah banyak dibudidayakan di berbagai wilayah. Pengembangan teknologi dan sistem produksi dalam bidang perikanan budidaya merupakan salah satu solusi utama bagi upaya peningkatan produksi ikan patin tersebut dengan cara mempersingkat lama waktu produksi benih patin. Untuk meningkatkan kualitas dan kuantitas benih sudah banyak dilakukan diantaranya melalui rekayasa lingkungan (Nugrahaningsih 2008).

Fujaya (1999) menyatakan, bahwa pengaruh lingkungan terhadap produksi hewan air bersifat ganda yakni tidak hanya berpengaruh terhadap keberlangsungan hidup ikan saja, tetapi berpengaruh juga terhadap kondisi biota akuatik lainnya dalam lingkungan tersebut. Sifat internal yang berupa genetik dan daya tahan terhadap penyakit bersifat tunggal yakni hanya berpengaruh terhadap kondisi ikan tersebut. Pada umumnya kegiatan budidaya ikan patin dibagi menjadi tiga kegiatan yakni pembenihan I, pembenihan II, dan pembesaran. Kegiatan pembesaran merupakan kegiatan untuk menghasilkan ikan berukuran konsumsi sebesar kurang lebih $250 \mathrm{~g} /$ ekor yang membutuhkan waktu kurang lebih 4 bulan masa pemeliharaan (Khairuman 2008). Salinitas berhubungan erat dengan tekanan osmotik dan ionik air. Hal ini disebabkan media bersalinitas mempengaruhi sistem osmoregulasi dalam tubuh ikan. Cairan tubuh ikan air tawar mempunyai tekanan yang lebih tinggi (hiperosmotik) daripada lingkungannya sehingga cenderung mengambil garamgaram yang berupa ion-ion $\mathrm{Na}+$ dan Cl- dari air melalui mekanisme difusi. Lingkungan bersalinitas $4 \mathrm{~g} / \mathrm{L}$ pada pemeliharaan ikan patin akan menjadikan kondisi mendekati isoosmotik sehingga memperkecil penggunaan energi untuk osmoregulasi kemudian dialihkan untuk pertumbuhan. Agar sel organ tubuh ikan dapat berfungsi dengan baik, maka sel-sel tersebut harus berada dalam cairan media (ekstraseluler) yang memiliki komposisi dan konsentrasi ionik yang sama dengan cairan dalam sel (intraseluler) (Fujaya 1999). Berdasarkan pernyataan Stickney (1979) channel catfish dapat hidup di air payau dengan salinitas mencapai $14 \mathrm{~g} / \mathrm{L}$. Indrati (1992) juga menyatakan bahwa pertumbuhan harian larva ikan patin meningkat dengan meningkatnya salinitas dari nol sampai dengan $4 \mathrm{~g} / \mathrm{L}$. Berdasarkan penelitian tersebut, peningkatan salinitas menjadi $4 \mathrm{~g} / \mathrm{L}$ pada media pemeliharaan benih ikan patin secara tidak langsung akan meningkatkan pertumbuhan.

Salah satu upaya optimasi pertumbuhan ikan diupayakan pula melalui penambahan mineral. Mineral tetap diperlukan oleh ikan untuk tumbuh dan berkembang. Sebanyak 2.50\% mineral di tubuh ikan catfish merupakan kalsium yang dapat diserap melalui media perairan (Hargreaves \& Tomasso 2004). Menurut Boyd (1982), kalsium juga dibutuhkan oleh ikan untuk proses osmoregulasi yang terjadi di dalam tubuh ikan dengan lingkungan serta penting untuk pembentukan tulang dan pembentukan kerangka luar dari krustasea. Kalsium merupakan mineral esensial yang diperlukan dalam jumlah yang cukup banyak. Kebutuhan kalsium dapat dipenuhi dengan penambahan kapur. Bahan pengapuran yang sering digunakan untuk pertanian yaitu $\mathrm{CaCO} 3$ (kalsit), CaMg (CO3)2 (dolomit), dan jenis kapur lainnya seperti $\mathrm{Ca}(\mathrm{OH}) 2$ dan $\mathrm{CaO}$. Westers (2001) vide Permatasari (2010) menyatakan bahwa kandungan kapur yang tersedia di kapur tohor $(\mathrm{CaO})(71 \%)$, kapur padam $(\mathrm{Ca}(\mathrm{OH}) 2)$ (54\%), dan kapur pertanian (CaCO3) (40\%) sehingga untuk mendapatkan pengaruh yang sama dibutuhkan masing-masing jenis kapur tersebut dengan perbandingan $1: 1.5: 2$. Penambahan kalsium ini akan meningkatkan pertumbuhan seperti untuk pembentukan tulang dan jaringan, sebagai contoh larva channel catfish tidak akan tumbuh dengan baik jika kandungan kalsium di perairan kurang dari $5 \mathrm{mg} / \mathrm{L}$ (Saputra 2000). Tujuan penelitian ini adalah untuk menganalisis pengaruh penambahan kalsium karbonat $(\mathrm{CaCO} 3)$ pada media bersalinitas terhadap pertumbuhan benih ikan patin.

\section{METODE PENELITIAN}

Penelitian ini dilaksanakan pada tanggal 1 Februari hingga 3 Maret 2012 bertempat di Laboratorium Lingkungan Akuakultur III, Departemen Budidaya Perairan, Institut Pertanian Bogor. Penelitian ini terdiri dari lima perlakuan yang masingmasing diberi tiga kali ulangan.

Perlakuan yang diberikan berupa pemberian kapur $\mathrm{CaCO} 3$ yang terdiri atas Kontrol (0 mg/L СaСО3), A (150 mg/L CaCO3), B (200 mg/L CaCO3), C (250 mg/L 
CaCO3) dan D (300 mg/L CaCO3). Kapur yang digunakan adalah $\mathrm{CaCO}_{3}$ dalam bentuk bubuk. Kapur $\mathrm{CaCO} 3$ ditambahkan ke dalam akuarium sesuai dengan dosis masing-masing pada media perlakuan yang sebelumnya sudah diisi air tawar bersalinitas $4 \mathrm{~g} / \mathrm{L}$ sebanyak 9 liter. Dosis yang diberikan untuk setiap perlakuan adalah $0 \mathrm{mg} / \mathrm{L} \mathrm{CaCO} 3,150 \mathrm{mg} / \mathrm{L} \mathrm{CaCO} 3$, $200 \mathrm{mg} / \mathrm{L} \mathrm{CaCO} 3,250 \mathrm{mg} / \mathrm{L} \mathrm{CaCO}_{3}$ dan $300 \mathrm{mg} / \mathrm{L} \mathrm{CaCO} 3$.

Wadah yang digunakan pada penelitian ini adalah 15 unit akuarium berdimensi $30 \times 15 \times 25 \mathrm{~cm}^{3}$. Akuarium dan tandon dibersihkan, kemudian didisinfeksi menggunakan larutan $\mathrm{KmnO}_{4}$ $20 \mathrm{mg} / \mathrm{L}$. Desinfeksi dilakukan selama 24 jam selanjutnya akuarium dan tandon dibilas dan dikeringkan selama 2 hari. Air yang digunakan berasal dari tendon yang sebelumnya telah diendapkan selama 3 hari. Akuarium yang sudah disiapkan diisi dengan air bersalinitas $4 \mathrm{~g} / \mathrm{L}$ sebanyak 9 liter. Air bersalinitas $4 \mathrm{~g} / \mathrm{L}$ diperoleh dengan melakukan penambahan garam krosok sebanyak $4 \mathrm{~g} / \mathrm{L}$ atau 36 gram per akuarium. Air bersalinitas tersebut kemudian diberi perlakuan dengan penambahan kapur $\mathrm{CaCO} 3$ masing-masing terdiri atas tiga ulangan. Setelah diaerasi selama 1 hari dan terjadi pengendapan, dihitung nilai kesadahannya. Setelah itu benih ikan patin dengan ukuran panjang $1-2 \mathrm{~cm}$ dan bobot 0.5-1 gram dimasukkan masing-masing sebanyak 4 ekor/L atau 36 ekor/akuarium kemudian dipelihara selama 30 hari.

Aklimatisasi dan adaptasi ikan dilakukan terhadap lingkungan pemeliharaan dan pakan komersial. Pakan yang diberikan pada awal pemeliharaan adalah 8\% dari biomassa, setelah sampling kedua menggunakan 5\% dari biomassa, setelah sampling ketiga menggunakan (3\%) dari biomassa. Untuk mempertahankan kualitas air dalam media pemeliharaan dilakukan pergantian air sebanyak $25-30 \%$ dari total volume air setiap 10 hari sekali.

\section{HASIL DAN PEMBAHASAN}

Derajat kelangsungan hidup atau survival rate (SR) benih ikan patin yang dipelihara dengan masa pemeliharaan 30 hari memiliki hasil yang sama untuk semua jenis perlakuan $0 \mathrm{mg} / \mathrm{L} \mathrm{CaCO} 3,150 \mathrm{mg} / \mathrm{L}$ CaCO3, $200 \mathrm{mg} / \mathrm{L} \mathrm{CaCO} 3,250 \mathrm{mg} / \mathrm{L} \mathrm{CaCO}_{3}$, dan $300 \mathrm{mg} / \mathrm{L}$ CaCO3 yakni sebesar (100\%) (Gambar 1).

Laju pertumbuhan harian terendah dicapai pada perlakuan kontrol $(0 \mathrm{mg} / \mathrm{L}$ $\mathrm{CaCO} 3)$ yakni sebesar $(11.51 \%)$ yang ditunjukkan oleh Gambar 2.

Minimnya kandungan mineral

$\mathrm{Ca}^{2+}$ dalam lingkungan kontrol membuat laju pertumbuhan harian ikan kurang maksimal. Penambahan kapur $\mathrm{CaCO} 3$ juga memberikan pengaruh nyata terhadap peningkatan bobot rata-rata benih patin. Hal tersebut juga ditunjukkan pada grafik bobot rata-rata (Gambar 3)

Perlakuan mengalami peningkatan bobot rata-rata pada semua perlakuan dari awal sampai akhir masa perlakuan. Peningkatan bobot rata-rata tertinggi terjadi pada perlakuan C (250 mg/L CaCO3) yakni berkisar 0.08-2.26 g/ekor dan terendah pada perlakuan kontrol $(0 \mathrm{mg} / \mathrm{L} \mathrm{CaCO} 3)$ yakni berkisar 0.08-1.62 g/ekor. Kapur $\mathrm{CaCO} 3$ juga memberikan pengaruh yang berbeda nyata terhadap pertumbuhan panjang ikan patin. Panjang mutlak ikan patin pada semua perlakuan mengalami peningkatan dengan kisaran $2.84-3.79 \mathrm{~cm}$. Panjang mutlak ikan tertinggi terdapat pada perlakuan $\mathrm{C}$ yakni penambahan $\mathrm{CaCO} 3$ sebanyak $250 \mathrm{mg} / \mathrm{L}$ dengan nilai $3.79 \mathrm{~cm}$ (Gambar 4).

Panjang mutlak terendah terdapat pada perlakuan kontrol yakni penambahan $\mathrm{CaCO} 3$ sebanyak $0 \mathrm{mg} / \mathrm{L}$ dengan nilai 2.84 $\mathrm{cm}$. Hal ini juga diperkuat dengan adanya grafik panjang rata-rata (Gambar 5) yang menunjukkan bahwa rata-rata pertambahan panjang tertinggi terdapat pada perlakuan $\mathrm{C}(250 \mathrm{mg} / \mathrm{L} \mathrm{CaCO} 3)$ yakni berkisar antara 2.71-6.50 cm. Sementara pertumbuhan panjang terendah terdapat pada perlakuan kontrol $0 \mathrm{mg} / \mathrm{L} \mathrm{CaCO}_{3}$ yakni berkisar 2.64$5.48 \mathrm{~cm}$

Berdasarkan data yang diperoleh, benih ikan patin mampu menyerap $\mathrm{Ca}^{2+}$ dengan baik dari perairan terdapat pada perlakuan C $(250 \mathrm{mg} / \mathrm{L} \quad \mathrm{CaCO} 3)$ yaitu dengan nilai kandungan mineral kalsium sebesar $0.23 \mathrm{mg}$ per individu. Kandungan $\mathrm{Ca}^{2+}$ terendah terdapat pada benih ikan patin perlakuan kontrol $\left(0 \mathrm{mg} / \mathrm{L} \mathrm{CaCO}_{3}\right)$ sebesar $0.11 \mathrm{mg}$ per individu. Secara umum, kandungan $\mathrm{Ca}^{2+}$ pada benih ikan patin meningkat dari konsentrasi awal sebelum perlakuan yaitu sebesar $0.90 \mathrm{mg}$ per individu. Hal ini diperkuat dengan grafik pertumbuhan baik bobot maupun panjang rata-rata selama pemeliharaan (Gambar 2, 3, 4 dan 5) yang terus meningkat. Berikut merupakan grafik kandungan kalsium yang terdapat pada benih ikan patin pada akhir masa pemeliharan. 


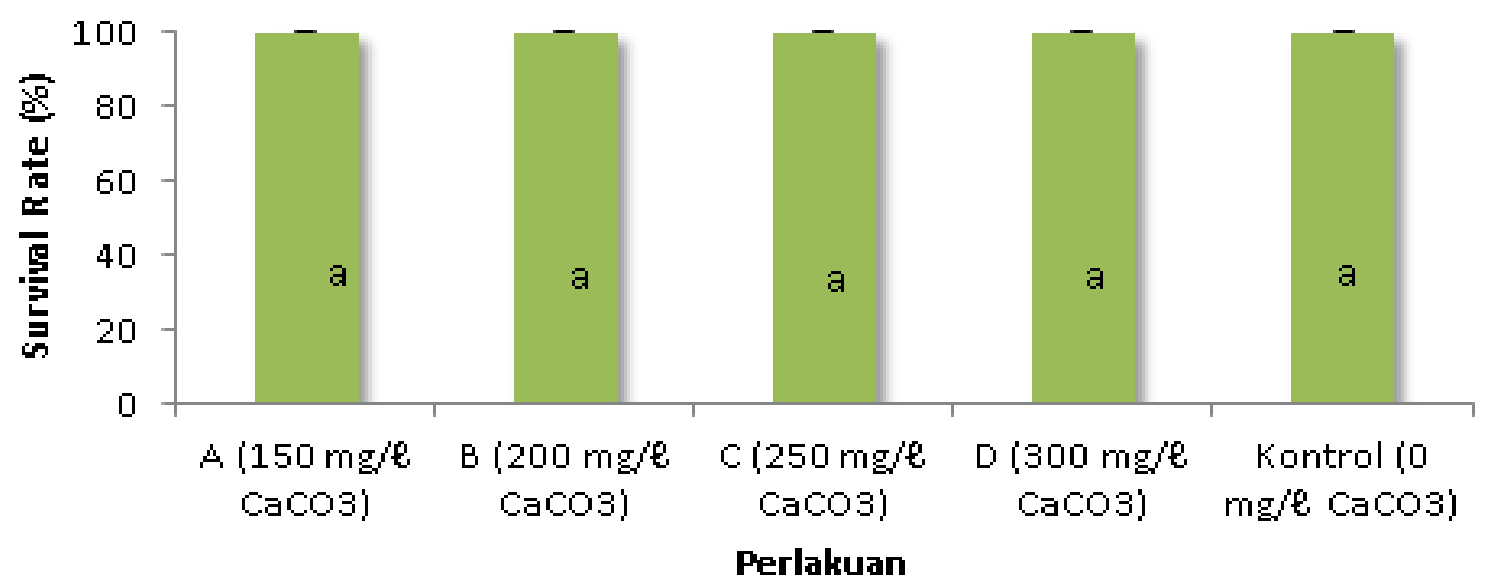

Gambar 1. Derajat kelangsungan hidup (survival rate, \%) benih ikan patin Pangasius $s p$. pada setiap perlakuan selama masa pemeliharaan

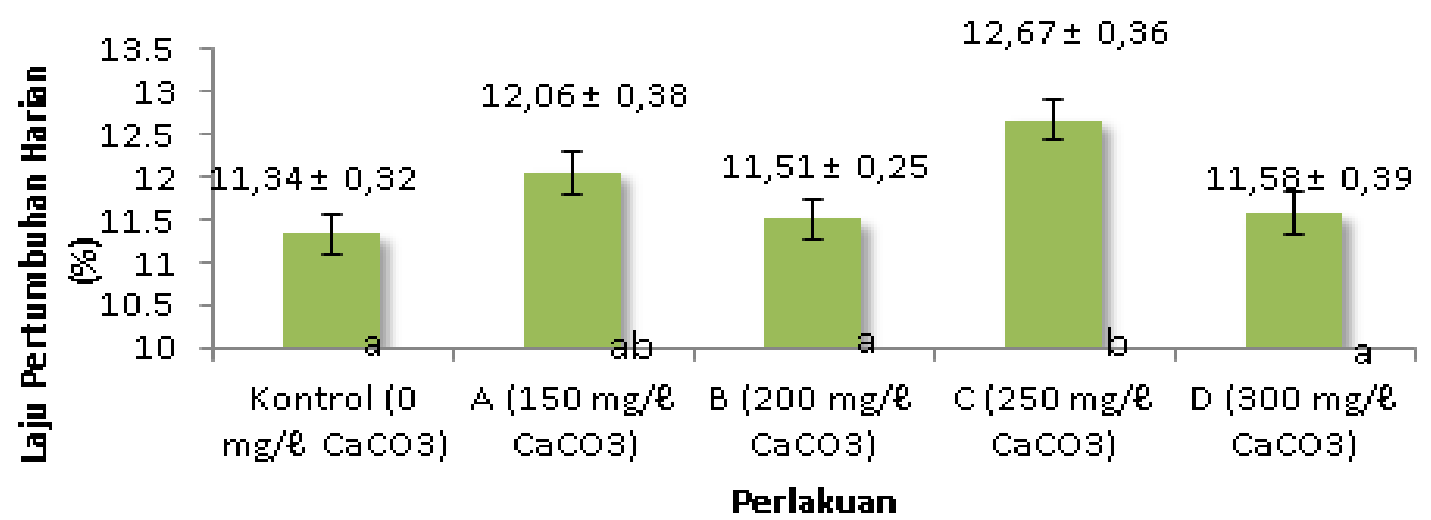

Gambar 2. Rata-rata pertumbuhan harian benih ikan patin Pangasius $s p$. pada setiap perlakuan selama masa pemeliharaan

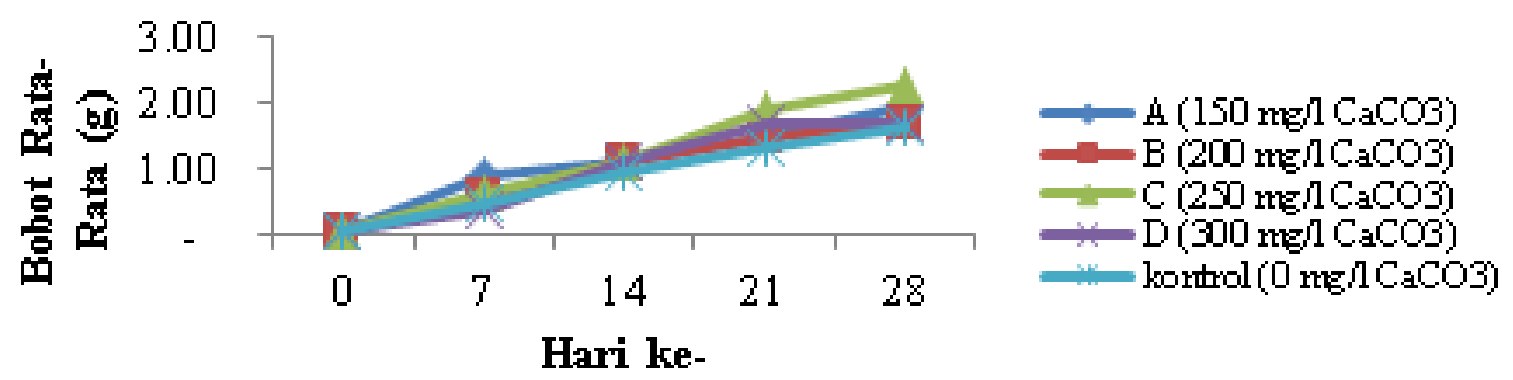

Gambar 3. Rata-rata bobot benih ikan patin Pangasius sp. pada setiap perlakuan selama masa pemeliharaan 


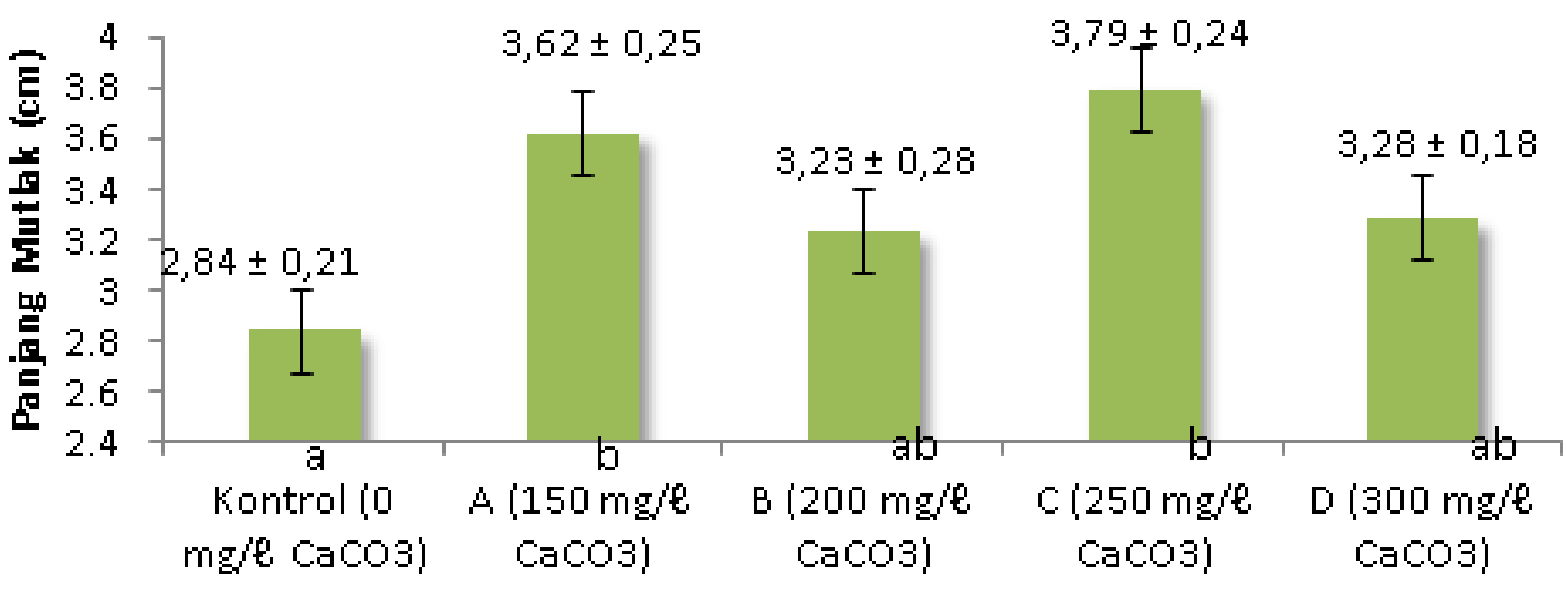

Perlakuan

Gambar 4. Panjang mutlak $(\mathrm{cm})$ benih ikan patin Pangasius $s p$. pada setiap perlakuan selama masa pemeliharaan

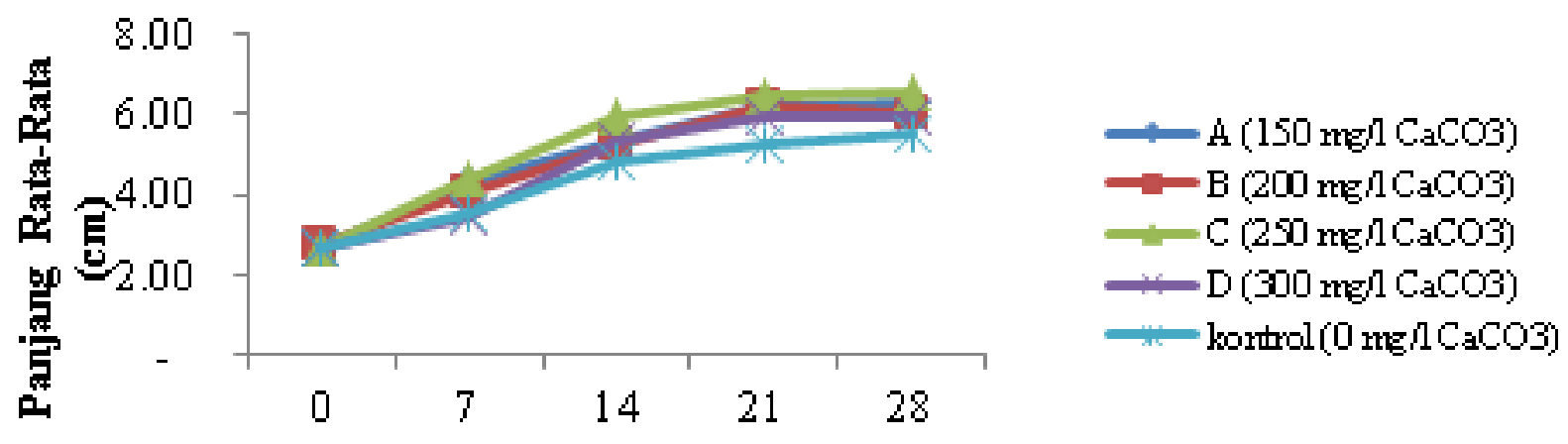

Pemeliharaan Hari ke-

Gambar 5. Rata-rata panjang (cm) benih ikan patin Pangasius sp. pada setiap perlakuan selama masa pemeliharaan

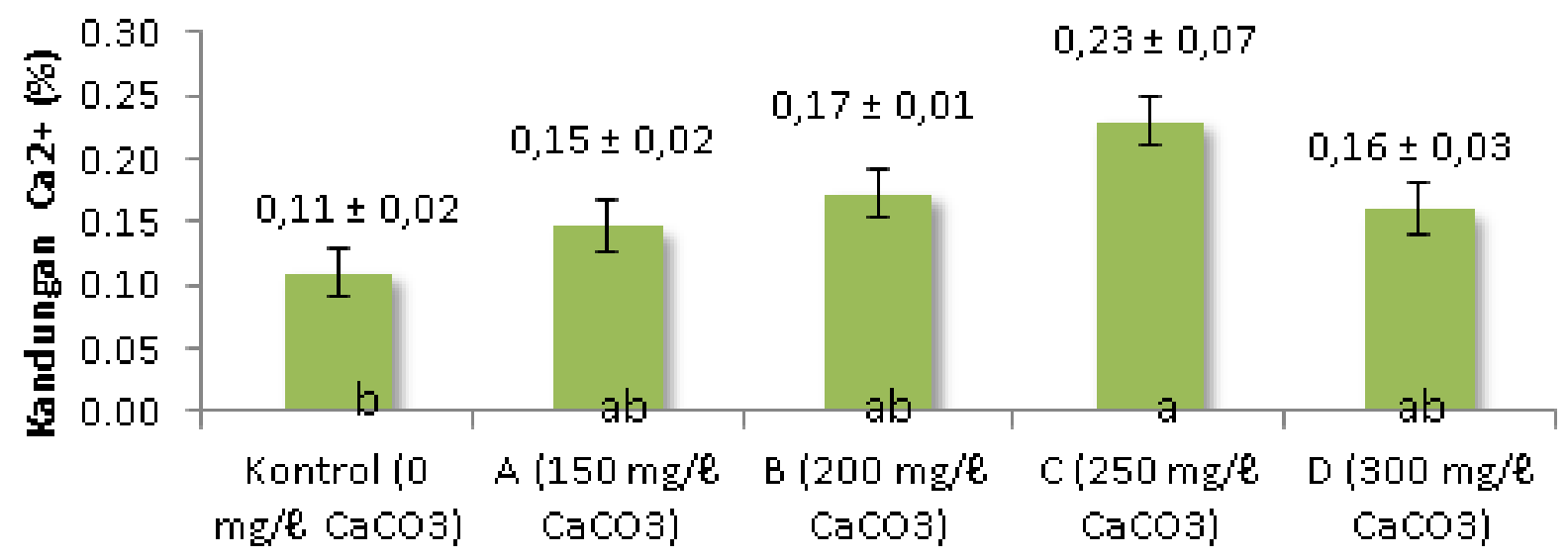

Perlakuan

Gambar 6. Kandungan $\mathrm{Ca}^{2+}$ benih ikan patin Pangasius sp. pada masa pemeliharaan 


\section{Pembahasan}

Maksimalnya derajat kelangsungan hidup yang diperoleh dari setiap perlakuan (100\%) ini dikarenakan konsentrasi kapur $\mathrm{CaCO} 3$ dalam air atau yang biasa disebut kesadahan masih dalam tahap yang dapat ditoleransi oleh ikan patin. Hal ini diperkuat dengan adanya pernyataan dari Effendi (2003) yang menyatakan bahwa parameter kesadahan untuk kegiatan budidaya bisa mencapai sebesar $500 \mathrm{mg} / \mathrm{L}$ CaCO3. Menurut Black (1957), kelangsungan hidup ikan air tawar di dalam lingkungan yang berkadar garam bergantung pada permukaan insang, laju konsumsi oksigen, toleransi jaringan tubuh terhadap garamgaram dan kontrol permeabilitas. Hal ini sesuai dengan pernyataan Survyta (1995) yang menunjukkan bahwa salah satu fungsi ginjal yakni sebagai salah satu organ osmoregulasi berfungsi memompa keluar kelebihan air dan menahan garam-garam mampu menjalankan fungsi secara baik sehingga benih ikan patin mampu bertahan.

Huet (1971) menyatakan bahwa pertumbuhan dipengaruhi oleh faktor internal dan eksternal. Faktor internal terdiri dari daya tahan terhadap penyakit dan genetik. Faktor eksternal meliputi faktor yang berkaitan dengan lingkungan tempat hidup serta ketersediaan makanan. Penelitian ini menguji faktor eksternal yaitu lingkungan terhadap pertumbuhan benih ikan patin. Penambahan kapur CaCO3 memberikan pengaruh nyata terhadap laju pertumbuhan bobot harian benih patin. Lovell (1977) menyatakan bahwa channel catfish dapat menyerap kalsium dari perairan. Kalsium diserap oleh tubuh melalui insang dan kulit (Lall 1989). Laju pertumbuhan harian selama pemeliharaan berkisar antara $11.51 \%-12.67 \%$. Laju pertumbuhan harian tertinggi dicapai pada perlakuan C (250 $\mathrm{mg} / \mathrm{L} \mathrm{CaCO} 3$ ) sebesar (12.67\%) (Gambar 2). Hal ini dikarenakan pada perlakuan tersebut, ikan patin mampu memanfaatkan kadar $\mathrm{Ca}^{2+}$ dalam perairan secara optimal untuk memaksimalkan pertumbuhan. Hal ini sesuai dengan data kandungan $\mathrm{Ca}^{2+} \mathrm{di}$ perairan yang menunjukkan laju penurunan kadar $\mathrm{Ca}^{2+}$ pada selang hari ke-0 sampai hari ke-10 kemudian perlahan meningkat pada selang hari ke-20 sampai akhir masa pemeliharaan. Hal ini membuktikan bahwa $\mathrm{Ca}^{2+}$ efektif diserap oleh benih ikan patin pada awal masa pemeliharaan.

Perbedaan yang nyata ini dipengaruhi oleh kandungan kalsium yang dapat dimanfaatkan oleh ikan pada perlakuan C sehingga fungsi kalsium sebagai pembentuk tulang dan jaringan dapat dimanfaatkan secara optimal untuk pertumbuhan panjang benih patin. Hal tersebut juga sesuai dengan pernyataan Steffens (1989) yang menyatakan kalsium memiliki fungsi sebagai komponen utama pembentuk tulang, gigi, kulit, serta sisik, dan memelihara ketegaran kerangka tubuh, mengentalkan darah, sebagai "intracellular regulator" yaitu membantu regulasi aktivitas otot kerangka, jantung dan jaringan lainnya, konstraksi dan relaksasi otot, membantu penyerapan vitamin B12, menjaga keseimbangan osmotik. Tiap jenis ikan membutuhkan jumlah kalsium yang berbeda. Mineral kalsium di lingkungan dapat berasal dari $\mathrm{CaCO} 3,(\mathrm{Ca}(\mathrm{OH}) 2)$ dan $\mathrm{CaO}$ (Kadarini 2009). Mineral-mineral kalsium tersebut mempunyai reaksi yang berbeda dalam air. Mineral kalsium yang berbeda akan memberikan tingkat pertumbuhan yang berbeda.

Selama pemeliharaan kualitas air berada dalam kisaran optimal untuk pertumbuhan ikan patin. Biota akuatik memiliki kisaran suhu tertentu untuk kelangsungan hidup dan pertumbuhannya. Peningkatan suhu menyebabkan kelarutan oksigen menurun dalam air, mempercepat metabolismedan respirasi, serta peningkatan konsumsi oksigen (Chainark S 2010). Suhu selama masa pemeliharaan ikan patin pada semua perlakuan berkisar antara 25.87$26.73{ }^{\circ} \mathrm{C}$. Karlina (2009) menyatakan bahwa suhu tersebut berada dalam kisaran yang optimal terhadap pertumbuhan benih ikan patin yaitu $24-32{ }^{\circ} \mathrm{C}$. Hal tersebut juga dapat dibuktikan dari data sintasan (SR) yang mencapai (100\%)dan data pertumbuhan (Gambar 2, 3, 4, dan 5) yang menunjukkan peningkatan pada semua perlakuan.

Budidaya ikan patin selain menggunakan air tawar ternyata dapat dilakukan di air payau. Berdasarkan pernyataan Qun (2012) bahwa channel catfish dapat hidup di air payau dengan salinitas mencapai $14 \mathrm{~g} / \mathrm{L}$. Selain itu pertumbuhan harian larva ikan patin meningkat dengan meningkatnya salinitas dari 0 g/L sampai dengan 4 g/L. Berdasarkan penelitian tersebut, peningkatan salinitas menjadi $4 \mathrm{~g} / \mathrm{L}$ pada media pemeliharaan benih ikan patin secara tidak langsung akan meningkatkan pertumbuhan. Hal ini disebabkan media bersalinitas mempengaruhi sistem osmoregulasi dalam tubuh ikan. Lingkungan bersalinitas 4 $\mathrm{g} / \mathrm{L}$ pada pemeliharaan ikan patin akan 
menjadikan kondisi mendekati isoosmotik sehingga memperkecil penggunaan energi untuk osmoregulasi kemudian dialihkan untuk pertumbuhan. Oleh karena itu pada penelitian ini salinitas yang digunakan sebesar 4 g/L. Kisaran nilai salinitas selama pemeliharaan berada pada nilai 4.13$4.82 \mathrm{~g} / \mathrm{L}$. Sebagian besar biota akuatik sensitif terhadap perubahan nilai $\mathrm{pH}$ dan menyukai nilai $\mathrm{pH}$ berkisar 7-8.50. Nilai $\mathrm{pH}$ selama masa pemeliharaan memiliki kisaran 6.94-8.18. Dengan demikian kapasitas buffer yang terkandung dalam kapur $\mathrm{CaCO} 3$ (dolomit) mampu menyangga dan meminimalkan fluktuasi nilai $\mathrm{pH}$. Menurut Effendi (2003) nilai $\mathrm{pH}$ di atas 10 dapat membunuh ikan, sementara nilai $\mathrm{pH}$ dibawah 5 mengakibatkan pertumbuhan ikan terhambat. Konsentrasi oksigen terlarut pada pemeliharaan ikan channel catfish sebaiknya tidak kurang $3 \mathrm{mg} / \mathrm{L}$ (Lawler 2010) Konsentrasi oksigen terlarut selama pemeliharaan berkisar antara 4.85$5.83 \mathrm{mg} / \mathrm{L}$. Berdasarkan kisaran yang diperoleh, kandungan oksigen terlarut di wadah perlakuan masih dalam batas toleransi kehidupan benih ikan patin.

Mortensen BM (2011) menyatakan bahwa konsentrasi amonia yang dapat ditoleransi oleh ikan adalah kurang dari $1 \mathrm{mg} / \mathrm{L}$. Senyawa ini berasal dari sisa metabolisme ikan dan perombakan bahan organik yang berasal dari sisa pakan yang tidak termakan. Dalam kadar tertentu, senyawa ini bisa menyebabkan keracunan dan kematian bagi ikan. Kandungan amonia pada media selama pemeliharaan berkisar antara 0.0002-0.0137 $\mathrm{mg} / \mathrm{L}$. Secara umum nilai amonia pada media pemeliharaan berada dalam konsentrasi yang sesuai dengan ketetapan APHA (1989) yang menyatakan konsentrasi amonia tidak boleh melebihi batas minimum ketetapan yaitu $0,01 \mathrm{mg} / \mathrm{L}$.

Ma Yan Qun (2012) menyatakan kesadahan pada dasarnya menggambarkan kandungan $\mathrm{Ca}^{2+}, \mathrm{Mg}^{2+}$ dan ion-ion polivalen lainnya seperti $\mathrm{Al}^{3+}, \mathrm{Fe}^{3+}, \mathrm{Mn}^{2+}, \mathrm{Sr}^{2+}$, dan $\mathrm{H}+$ yang terlarut dalam air. Dari hasil yang diperoleh diketahui bahwa kisaran nilai kesadahan pada awal pemeliharaan adalah 301.50-488.95 mg/L CaCO3. Untuk nilai kesadahan $\mathrm{Ca}^{2+}$ menunjukkan bahwa nilai kesadahan pada awal pemeliharaan sampai akhir pemeliharaan cenderung mengalami penurunan yang cukup drastis yakni berkisar antara 172.66-57.06 mg/L CaCO3. Menurunnya kadar $\mathrm{Ca} 2+$ dalam perairan menjadi indikasi bahwa ikan patin mampu memanfaatkan $\mathrm{Ca}^{2+}$ (kalsium) untuk pertumbuhan. Hal ini dapat dibuktikan dengan adanya grafik pertumbuhan bobot dan panjang rata-rata selama pemeliharaan (Gambar 3 dan 5) yang menunjukkan adanya peningkatan bobot serta panjang yang cukup signifikan. Menurut Borges (2013) perairan sangat sadah mengandung kalsium, magnesium, karbonat dan sulfat yang sangat tinggi yang sangat berguna untuk pertumbuhan biota akuatik dalm jumlah tertentu. Kegiatan pembesaran merupakan kegiatan untuk menghasilkan ikan berukuran konsumsi sebesar kurang lebih $250 \mathrm{~g} /$ ekor yang membutuhkan waktu kurang lebih 4 bulan masa pemeliharaan (Khairuman 2008).

\section{KESIMPULAN}

Penambahan kalsium karbonat (CaCO3) dengan konsentrasi yang berbeda pada media bersalinitas $4 \mathrm{~g} / \mathrm{L}$ berpengaruh nyata bagi laju pertumbuhan bobot harian benih patin dan panjang mutlak benih patin. Laju pertumbuhan bobot dan panjang terbaik terdapat pada perlakuan $\mathrm{C}$ yaitu dengan penambahan $\mathrm{CaCO}_{3}$ sebanyak 250 $\mathrm{mg} / \mathrm{L}$ ke dalam media perlakuan.

\section{DAFTAR PUSTAKA}

APHA (American Public Health Association), 1989. Standard Methods for the Examination of Water and Wastewater, 17th edn. American Public Health Association. Washington DC.

Black VS. 1957. Excretion and Osmoregulation. In Brown, M.E.(Ed). The Physiology of Fisheries, Vol.1. Academic Press. New York.

Borges MT. 2011. Water quality monitoring in aquaculture as a remote laboratory proxy for environmental studies. Journal of Emerging Technologies in Learning. VOL 6.

Boyd CE. 1982. Water Quality Management for Pond Fish Culture. Amsterdam. Owxord New York. Elsavier Scientific Publishing Company.

Chainark S. 2010. Water and sediment quality, phytoplankton communities, and channel catfish production in sodium nitrate-treated ponds. Journal of Applied Aquaculture. VOL 22.

Effendi H. 2003. Telaah Kualitas Air Bagi Pengelolaan Sumberdaya dan Lingkungan Perairan. Yogyakarta: Kanisius. 
Farmer GJ, Beamish FWH. 1969. Oxygen consumption of Tilapia nilotica in relation to swimming speed and salinity. J. fish res.

Fujaya Y. 1999. Fisiologi Ikan. Yakarta :Rineka Cipta.

Hargreaves JA, Tomasso JR. 2004. Environment, in: Tucker, C.S., Tomasso, J.R., Biology and Culture of Channel Catfish. Elsevier.

Huet M. 1971. Text book of fish culture, Breeding and Cultivation of fish. Fishing News, London.

Indrati Y. 1992. Pengaruh berbagai tingkat salinitas terhadap derajat penetasan telur, kelangsungan hidup, dan pertumbuhan larva ikan Jambal Siam Pangasius sutchii [Skripsi]. Bogor : Institut Pertanian Bogor.

Kadarini T. 2009. Pengaruh salinitas dan kalsium terhadap kelangsungan dan pertumbuhan benih Balashark balantiochilus melanopterus [Tesis]. Bogor : Institut Pertanian Bogor

Karlina L. 2009. Efektivitas penambahan kapur $\mathrm{CaO}$ pada media pemeliharaan bersalinitas $4 \mathrm{~g} / \mathrm{L}$ terhadap kelangsungan hidup dan pertumbuhan ikan patin. [Skripsi]. Bogor : Institut Pertanian Bogor.

Khairuman A. 2008. Budidaya Ikan Patin. Jakarta: Argo Media Pustaka.

KKP (Kementrian Kelautan dan Perikanan), 2011. Pasok patin dunia, RI segera geser Vietnam. http://www.dkp.go.id. [10 mei 2012].

Lall 1989. The mineral in: JE halver ed Fish Nutrition. New York : Academic press

Lawler DF. 2010. The effect of antiscalant addition on calcium carbonate precipitation for a simplified synthetic brackish water reverse osmosis concentrate. Journal of Water Research. VOL 44 (9):2957-2969.

Lovell RT. 1977. Nutrition and Feeding of Channel catfish. Southern Cooperative Series Bulletin 218.

Ma Yan Q, Kai H, HuiMin W, LiPing L, XiYing B. 2012. Effects of dietary phospholipids on $\mathrm{Na}+-\mathrm{K}+-\mathrm{ATPase}$ activity and cell membrane fatty acid composition in gill of catfish (Pangasius sutchi). Journal of Animal Husbandry and Feed Science Vol. 4:285-288.

Mortensen BM, DeJong JT. 2011. Effects of environmental factors on microbial induced calcium carbonate precipitation. Journal of Applied Microbiology. VOL 111:338-349.

Nugrahaningsih KA. 2008. Pengaruh tekanan osmotik media terhadap tingkat kelangsungan hidup dan pertumbuhan benih ikan patin (Pangasius sp.) pada Salinitas $5 \mathrm{~g} / \mathrm{L}$. [Skripsi]. Bogor : Institut Pertanian Bogor.

Saputra R. 2000. Pengaruh konsentrasi kalsium media terhadap kelangsungan hidup dan pertumbuhan larva ikan jambal siam (Pangasius sp.) [Skripsi]. Bogor: Institut Pertanian Bogor.

Stickney R. 1979. Principles of Warmwater Aquaculture. John Wiley, New York.

Steffens W. 1989. Principles of Fish Nutrition. John Wiley, New York.

Survyta I. 1995. Pengaruh Perubahan Salinitas dari 0 permil ke 3 permil, 6 permil dan tetap terhadap produksi benih ikan jambal siam (Pangasius sutchi fowler) [Skripsi]. Bogor: Institut Pertanian Bogor. 